Article

\title{
Assessments of Landowners' Willingness to Accept Compensation for Participating in Forest Certification in Shandong, China
}

\author{
Nana Tian ${ }^{1, * \mathbb{D}}$, Neelam Poudyal ${ }^{2}$ and Fadian $\mathrm{Lu}^{3}$ \\ 1 College of Forestry, Agriculture \& Natural Resources, University of Arkansas at Monticello, \\ 110 University Court, Monticello, AR 71656, USA \\ 2 Department of Forestry, Wildlife \& Fisheries, University of Tennessee, 274 Plant Science Bldg., \\ Knoxville, TN 37996, USA; npoudyal@utk.edu \\ 3 Department of Forestry, Shandong Agricultural University, 61 Daizong Str., Taishan, Tai'an 271017, China; \\ lfd@sdau.edu.cn \\ * Correspondence: tian@uamont.edu
}

check for

updates

Citation: Tian, N.; Poudyal, N.; Lu, F. Assessments of Landowners' Willingness to Accept Compensation for Participating in Forest Certification in Shandong, China. Sustainability 2021, 13, 903. https:// doi.org/10.3390/su13020903

Received: 13 August 2020

Accepted: 12 January 2021

Published: 18 January 2021

Publisher's Note: MDPI stays neutral with regard to jurisdictional claims in published maps and institutional affiliations.

Copyright: (c) 2021 by the authors. Licensee MDPI, Basel, Switzerland. This article is an open access article distributed under the terms and conditions of the Creative Commons Attribution (CC BY) license (https:/ / creativecommons.org/licenses/by/ $4.0 /)$.

\begin{abstract}
Achieving sustainable management of forests in China is becoming increasingly important with more awareness and realization of the importance of forests in environmental protection. Forest certification, a market-based instrument to promote sustainable forest management, has been recognized by many countries including China. While landowners' perception and perspective regarding this voluntary program have been well-documented in the literature, how to motivate and incentivize landowners to participate in forest certification remained understudied questions. With the face-to-face survey of landowners in Shandong, China, this study analyzed landowners' willingness to accept compensation for participating in forest certification. Results indicated that the average accepted compensation in terms of increased timber price was about RMB 120 ( USD 17.6) $/ \mathrm{m}^{3}$ to have their forests enrolled in certification programs. Results from multiple regression showed that the level of such compensation required for participation in certification was influenced by forestland size, owner demographics, certification-program requirements, and importance placed on timber production. These findings would inform policy-makers in designing compensation-related policies and establish incentive-based mechanisms to motivate forest landowners to participate in forest certification programs in China.
\end{abstract}

Keywords: forest certification; willingness to accept; compensation; landowners; timber price increase

\section{Introduction}

Achievement of sustainable forest management for environmental, social and economic benefits is the aim of China's modern (after $1990 \mathrm{~s}$ ) forestry development as natural forests are being depleted because of overharvesting of timber over its history [1-3]. In China, example practices of sustainable forest management include restoration of degraded landscape and improvement of forest ecology and biodiversity through government initiatives and policies [3]. Forest certification as a market-based mechanism has been recognized in China in the $1990 \mathrm{~s}$ and the function in promoting forest management level has also been affirmed. Therefore, Chinese officials began to explore and develop forest certification systems from 2001 based on China's forestry conditions and thus far, China has three major certification programs including the Forest Stewardship Council (FSC), Programme for the Endorsement of Forest Certification schemes (PEFC), and China Forest Certification Council (CFCC). Both the FSC and PEFC are internationally recognized certification schemes and the difference is that wood processors (in addition to other entities) are more involved in the origin of the PEFC. The CFCC system is a program developed by China itself and is endorsed by the PEFC. Although there are differences in the certification schemes' stan- 
dards and processes, they all envision the sustainable and responsible management of forest resources.

China has made great progress in forest certification over the past decade such as the certified forests area has experienced a great increase; specifically, the area of certified forests has exceeded 9 million hectares in 2016 which comprises around $4.3 \%$ of the total forest area in China [4]. By definition, forest certification is a program established by non-government agencies to promote sustainable forest management and, actually, this program also provides an opportunity for landowners to have a formal and independent assessment for their property according to the predefined sustainable management standards [5]. As a result, improving landowners' knowledge and understanding for forest certification and motivating them to participate in accessible certification programs also plays a significant role in meeting the objective of sustainably and responsibly managing forest resources globally.

The major drivers for landowners in China to seek forest management certification are improving forest management and expanding market access. There is a time in China with widespread overharvesting and illegal logging which results in a depletion of forests and severe natural disasters (e.g., flooding) [1-3]; since then, Chinese officials realized the necessity and urgency of combating deforestation by improving forest management, and forest certification is a good mechanism to adopt. Another important driver for seeking forest management certification is market accessibility. For China, as a major provider of intermediate forest products, it is imperative to adopt certification schemes to maintain and expand its market share. Forest management certification, as a market-based mechanism, could help achieve these objectives in China, including promoting sustainable forest management and helping market access such as US and European markets. Take Linyi city in Shandong Province as an example; as reported, there were about 1800 hectares' of poplar plantation forests certified under the FSC scheme in 2013 and, meanwhile, this area is a major provider of different timber products for IKEA [6]. Comparing with the total forest area of 2.55 million hectares in Shandong, there is a necessity to further increase the visibility of forest certification and establish an incentive-based mechanism to encourage landowners to participate in forest certification programs.

Regarding the research of forest certification among landowners, the existing literature mostly focuses on the research areas of identifying landowners' concerns and challenges to participate in forest certification as well as investigating their perceptions and attitudes towards certification programs. For example, one key concern for landowners to have their property certified was the costs associated with certification [7-18]. To be specific, Tian et al. [17] reported that increased management costs was significantly and negatively associated with landowners' willingness to participate in forest certification in Shandong Province, China. Studies also showed that the stringent requirements of certification program such as requirement of a written management plan $[8,10,17,18]$ was another landowner's concern for seeking forest certification. For example, Kilgore et al., [19] and Leahy et al. [12] reported that the requirement of a forest management plan was a barrier for family landowners to adopt forest certification with a survey conducted in Minnesota. Last, but not the least, the lack of price premiums and market preference $[9,10,12,17,19]$ for certified timber was also an important barrier for landowners to adopt forest certification.

In addition, numerous studies have attempted to identify profiles of landowners who are likely to participate in the forest certification program. For example, both Tian et al. [18] and Ma et al. [14] stated that landowners who were wealthier and more educated appeared to be more likely to participate in forest certification; in addition, some studies [20-22] indicated that female landowners were more inclined to engage in environment-friendly programs including the certification program. Moreover, research has shown that landowners' occupation was also an influencing factor for their likelihood of participating in forest certification $[14,17,18,23,24]$. The explanation in these studies was that landowners' familiarity with programs and forestry practices because of their forestry-related occupations might increase their interests in participation. Besides, landowners with a larger acreage 
size of forestland and those who intend to harvest timber shortly were more likely to adopt certification than otherwise $[14,17,18]$. Furthermore, the research of Bell et al. [23] and Tian et al. [18] reported that landowners who have a management plan for their forestland were more likely to adopt certification than their counterparts, which was ascribed to landowners' previous experience with forest management positively associated with their willingness to participate in forest stewardship programs.

The literature thus far provides a good perspective on landowners' awareness and perceptions of forest certification and their potential concerns/challenges. What is scarce in certification literature is an estimation of the compensation necessary for landowners to certainly participate in a certification program. Since landowners who are considering enrolling in certification may face a small cost of participation (e.g., third-party verification fee, potential harvest reduction, added cost in implementation of best management practices), it may not be financially worthwhile for many without some compensation or increase in timber price. In addition, understanding what specific attributes of forest ownership, forest households' demographics, and requirements of certification program schemes impact the necessary compensation is important in designing incentive-based programs. Therefore, the objectives of this study were to (1) investigate landowners' familiarity and attitudes towards forest certification, (2) examine differences in ownership and forestland characteristics among subgroup landowners, and (3) estimate landowners' average willingness to accept (WTA) compensation for participating in forest certification and identify factors influencing it. Through identifying the characteristics of landowners associated with an accepted WTA compensation for participating in forest certification programs, this study could provide useful information for policy-makers in designing compensation-related policies and establish incentive-based mechanisms to motivate landowners to enroll in certification programs in Shandong and elsewhere.

\section{Materials and Methods}

\subsection{Data Collection}

Data for this study were collected in 2016 from the Shandong province of China using a face-to-face survey (Supplementary Materials). The survey was reviewed and approved on 20 June 2016 by the University of Tennessee's Institutional Review Board (IRB 16-02999-XP) before implementing. Shandong Province is a coastal province located in the East China region. There is a diverse geomorphologic pattern in Shandong, which has mountainous and hilly areas in both the east and west as well as the center; in addition, there are great plain areas in the north west of Shandong which were formed by the alluviation of the Yellow River. Besides, there are also coastal areas which mainly located in the northeast and southeast regions. The diverse and unique geographical location brings about rich plant species and, regarding forest vegetation, has 615 species and is dominated by broad-leaf deciduous forest. In terms of climate, this province is located in a monsoon climate region with a moderate warm temperate monsoon climate. The annual average temperature and precipitation is around $11-14{ }^{\circ} \mathrm{C}$ and $550-950 \mathrm{~mm}$, where most of $(60-70 \%)$ the rainfall precipitation happens in summertime between June and August. To increase timber production and forest cover, the forest sector in this province focuses on expanding both industrial plantations and ecological afforestation since the 1990s. A famous project in this province is the Shandong Ecological Afforestation Project which was implemented during the period of 2010 2015. The industrial timber production forest in Shandong mainly refers to the fast-growing and high-yield poplar forests $[17,25]$. The forest area in this province is, in total, around 2.55 million hectares which is mainly distributed on the mountainous and hilly areas as well as the coastal areas. The survey conducted in this study were completely in six heavily forested cities including Taian, Jinan, Linyi, Liaocheng, Jining, and Weifang, which are located in the mountainous and coastal areas.

The target population for this survey was forestland households in Shandong Province. The survey was administered under the help of local forest officials, who provided in- 
formation about who owns forests locally and a random sample was then selected to approach either at their residences or at their forestlands. The dominated tree species among the interviewed landowners is poplar forests. Taking Linyin as an example, the total poplar plantation area is about 200 thousand hectares [6]. The questionnaire was filled by totally 557 landowners (households in China have time-limited (generally between 30 and 70 years) forest use and management rights and this kind of "ownership" is ascribed to China's forest land tenure. To make this term understandable, we use "landowners" in this study for those households who currently have land use and management rights.) and 50 of them did not finish the questions in the survey, so we had 507 usable completed surveys. Survey questions primarily included Likert scale items of various scales (e.g., $1=$ not familiar at all, $5=$ extremely familiar; $1=$ not interested at all, $4=$ very interested). We also included an open-ended WTA question asking about landowners' minimal acceptable timber price $\left(\mathrm{RMB} / \mathrm{m}^{3}\right)$ increase (percentage increase from the current price) to definitely participate in a forest-management certification program. Other survey questions included questions regarding ownership and forestland characteristics (e.g., forestland size, tenure, intent to harvest timber, acquisition mode of forestland by landowners), and the likelihood of participating in certification if the program had a given condition of participation and sociodemographic information (e.g., age, gender, income, education, occupation, and living area) about landowners $[17,18]$. In addition to the survey questions, the secondary data of the poplar timber price were collected.

\subsection{Econometric Model}

We hypothesis that landowners' awareness and knowledge of forest certification might positively correlate with their interest level in adopting a forest certification program; therefore, to test the correlation between landowners' familiarity with forest certification and their interest level in participating in a certification program, Kendall's rank correlation tau was used. Kendall's rank correlation is a traditional correlation method for two ordinal variables [26]. Meanwhile, analysis of variance (ANOVA) was employed to test for differences in subsequent groups of not familiar and familiar groups at a 0.05 significance level. The associated information of forestland and ownership characteristics, as well as landowners' demographics, were tested to further describe the subgroup households.

Following Lindhjem and Mitani [27] and Beach et al. [28], landowners' WTA compensation can conceptually be specified as a function of resource conditions (e.g., forestland condition), ownership characteristics, conservative program (e.g., forest certification) requirements, and market drivers (e.g., interest rate, timber price, etc.). specifically, the function is expressed as (Equation (1)):

$$
W T A=f(F R, O C, C P, O T)
$$

where: $F R$ is a vector of forestland characteristics such as land size, harvesting plan, etc., $O C$ includes owners' sociodemographic variables such as age, gender, income and education, etc. $P R$ denotes a vector of variables associated with certification program design characteristics such as whether a management plan was required for participating in a forest certification scheme, etc. OT mainly represents other variables such as timber price and interest rate, etc.

Regarding the willingness to pay (WTP)/WTA data collected with an open-ended question, a very traditional analysis method is the ordinary least squares method (OLSs) [27], but this statistical method has a requirement that the data distribution is a peculiar distribution. However, the WTA data gathered in this study are a continuous positive variable indicating landowners' acceptable compensation amount. As a result, the econometric estimation approach employed was the Tobit model [29-32]. The dependent variable was landowners' acceptable timber price increase $\left(\mathrm{RMB} / \mathrm{m}^{3}\right)$ for participating in a forest management certification program. This regression model was undertaken in the software of Statistical Analysis System (SAS). Landowners' WTA compensation was measured in terms of percentage increase in timber price from the average price of past fifteen years. 
To be specific, respondents' indicated that the percentage increase in timber price was multiplied by the average timber price at the time of the survey (RMB660 ( USD 96.5)/ $\mathrm{m}^{3}$ ) to quantify the monetary amount of compensation. Independent variables consisted of variables related to ownership and forestland characteristics (e.g., tenure and land size), owner sociodemographic, as well as program design characteristics. Table 1 presents the description, mean and standard deviation (S.D.) for both dependent and potential influential explanatory variables that were used for empirical analysis. The Tobit model is presented as Equation (2):

$$
W T A_{i}^{*}=\beta_{0}+\beta x+\varepsilon_{i} W T A_{i}=\max \left(0, W T A_{i}^{*}\right)
$$

where: $x$ is the matrix of all possible independent variables included in this study, and $\beta$ represents the vector of coefficients, and $\varepsilon_{i}$ is the error term which follows a normal distribution.

Table 1. Explanatory variables used to explain landowners accepted compensation for adopting forest certification $(n=507)$.

\begin{tabular}{|c|c|c|}
\hline Variable & Mean (S.D.) & Description \\
\hline \multicolumn{3}{|r|}{ Dependent variable } \\
\hline PRICEINC & $122.9(49.26)$ & $\begin{array}{l}\text { Minimum increase in timber price required by respondents in order to } \\
\text { certainly participate in forest certification }\left(\mathrm{RMB} / \mathrm{m}^{3}\right)\end{array}$ \\
\hline \multicolumn{3}{|r|}{ Independent variables } \\
\hline \multicolumn{3}{|c|}{ Forest resource characteristics } \\
\hline SIZE & $139.9(91.20)$ & Hectares of forestland \\
\hline IMPBIO & $3.55(1.27)$ & $\begin{array}{l}\text { Importance of forestland in protecting nature and biodiversity }(1=\text { not } \\
\text { important, } 5=\text { extremely important })\end{array}$ \\
\hline IMPREC & $2.71(1.08)$ & $\begin{array}{l}\text { Importance of forestland for recreation }(1=\text { not important, } 5=\text { extremely } \\
\qquad \text { important })\end{array}$ \\
\hline \multicolumn{3}{|c|}{ Acquisition mode of forestland } \\
\hline Purchase & $0.54(1.34)$ & Dummy variable, whether purchased forestland $(\mathrm{Yes}=1, \mathrm{No}=0)$ \\
\hline Inherit & $\begin{array}{c}0.34 \\
(0.47)\end{array}$ & Dummy variable, whether inherited forestland (Yes = 1, No = 0) \\
\hline Rent/trade & $0.50(0.50)$ & Dummy variable, whether rent/traded forestland $(\mathrm{Yes}=1, \mathrm{No}=0)$ \\
\hline TENURE & $21.89(20.48)$ & Number of years forestland has been managed by landowners \\
\hline FUHAR & $0.92(0.85)$ & $\begin{array}{l}\text { Dummy variable, whether landowners intend to harvest timber in the near } \\
\text { future }(1=\mathrm{Yes}, 0=\mathrm{No})\end{array}$ \\
\hline MANAPLAN & $0.52(0.50)$ & $\begin{array}{l}\text { Dummy variable, whether landowners have a management plan }(1=\text { Yes, } \\
\qquad 0=\mathrm{No})\end{array}$ \\
\hline \multicolumn{3}{|r|}{ Conditions of participation } \\
\hline RMNP & $0.60(0.49)$ & $\begin{array}{l}\text { Dummy variable of if participation would require having a management } \\
\text { plan ( } 1=\text { somewhat or definitely likely to participate, } 0=\text { otherwise). }\end{array}$ \\
\hline ROPI & $0.51(0.50)$ & $\begin{array}{l}\text { Dummy variable }(1=\text { respondent agrees that allowing periodic on-site } \\
\text { inspections of forestry practice is a drawback associated with participating, } \\
0=\text { otherwise). }\end{array}$ \\
\hline
\end{tabular}


Table 1. Cont.

\begin{tabular}{|c|c|c|}
\hline Variable & Mean (S.D.) & Description \\
\hline RPFMH & $0.65(0.49)$ & $\begin{array}{l}\text { Dummy variable of if participation would require using a professional } \\
\text { forester to manage and harvest forestland }(1=\text { somewhat or definitely likely } \\
\text { to participate, } 0=\text { otherwise }) .\end{array}$ \\
\hline RICP & $0.62(0.49)$ & $\begin{array}{l}\text { Dummy variable of if participation would require involvement in some part } \\
\text { of certification process }(1=\text { somewhat or definitely likely to participate, } 0= \\
\text { otherwise })\end{array}$ \\
\hline RIRP & $0.49(0.50)$ & $\begin{array}{l}\text { Dummy variable of if participation would require making results of on-site } \\
\text { inspections fully available to the public }(1=\text { somewhat or definitely likely to } \\
\text { participate, } 0=\text { otherwise })\end{array}$ \\
\hline \multicolumn{3}{|r|}{ Sociodemographic variables } \\
\hline Age & $37.81(8.77)$ & Age of landowners (years) \\
\hline Gender & $0.71(0.45)$ & Gender of landowners $(1=$ male, $0=$ female $)$ \\
\hline \multicolumn{3}{|r|}{ Education level } \\
\hline Bachelor/higher & $0.61(0.49)$ & $\begin{array}{l}\text { Dummy variable, whether the landowner has more than college education } \\
\qquad(Y e s=1, \text { No }=0)\end{array}$ \\
\hline High school/vocational training & $0.27(0.45)$ & $\begin{array}{l}\text { Dummy variable, whether the landowner has more than high school } \\
\text { education (Yes }=1, \text { No }=0)\end{array}$ \\
\hline Did not complete high school & $0.12(0.32)$ & $\begin{array}{l}\text { Dummy variable, whether the landowner has less than high school } \\
\text { education (Yes }=1, \text { No }=0)\end{array}$ \\
\hline Income & $2.30(0.85)$ & $\begin{array}{c}\text { Annual income of landowners }(1=\text { Less than } \mathrm{RMB} 20,000,2=\mathrm{RMB} \\
20,000-50,000,3=\mathrm{RMB} 50,000-75,000,4=>\mathrm{RMB} 75,000)\end{array}$ \\
\hline \multicolumn{3}{|r|}{ Occupation of landowners } \\
\hline Forester & $0.07(0.25)$ & Dummy variable, if the landowner is a forester $(Y e s=1$, No $=0$ ) \\
\hline Professional manager & $0.58(0.91)$ & $\begin{array}{l}\text { Dummy variable, if the landowner is a professional manager }(\text { Yes }=1 \text {, } \\
\qquad \text { No }=0)\end{array}$ \\
\hline Government employee & $0.07(0.25)$ & $\begin{array}{l}\text { Dummy variable, if the landowner is a government employee (Yes = 1, } \\
\qquad \text { No }=0)\end{array}$ \\
\hline Farmer & $0.41(0.49)$ & Dummy variable, if the landowner is a farmer $(\mathrm{Yes}=1, \mathrm{No}=0)$ \\
\hline \multicolumn{3}{|l|}{ Living area } \\
\hline Metropolitan/suburb & $0.23(0.42)$ & $\begin{array}{l}\text { Dummy variable, if the landowner lives in a metropolitan/suburb area } \\
\qquad(\text { Yes }=1, \mathrm{No}=0)\end{array}$ \\
\hline Town/county & $0.44(0.50)$ & $\begin{array}{l}\text { Dummy variable, if the landowner lives in a town/county area (Yes =1, } \\
\qquad \mathrm{No}=0)\end{array}$ \\
\hline Rural/village & $0.33(0.47)$ & $\begin{array}{l}\text { Dummy variable, if the landowner lives in a rural/village area (Yes =1, } \\
\qquad \text { No }=0)\end{array}$ \\
\hline DEPFOR & $39.97(28.73)$ & Percentage of household income derived from the forestland (\%) \\
\hline \multicolumn{3}{|l|}{ Others } \\
\hline IMPTIM & $3.62(1.29)$ & $\begin{array}{l}\text { Importance placed by landowners on timber production as ownership } \\
\text { objective }(1=\text { not important, } 5=\text { extremely important })\end{array}$ \\
\hline FAMI & $2.47(1.08)$ & $\begin{array}{l}\text { Landowners' familiarity with forest certification }(1=\text { not familiar at all, } 5= \\
\text { very familiar })\end{array}$ \\
\hline INTERE & $0.40(0.49)$ & $\begin{array}{l}\text { Dummy variable }(1=\text { landowner indicated slight, some, or high level of } \\
\text { interest in adopting forest certification, } 0=\text { otherwise })\end{array}$ \\
\hline
\end{tabular}

The group of forest resource characteristics $(F R)$ variables included forestland size, management objective of forestland, acquisition mode of forestland, tenure, timber harvest history, and whether it had a management plan. The management objective related 
variables primarily concerning the importance of forestland for recreation (e/g., family gathering, scenic view, etc.) and timber production, as well as in protecting nature and biodiversity. The acquisition mode of forestland mainly included the purchase, inherit, and trade/rent options and for each option, we coded it as a dummy variable (Table 1). Timber harvest history consisted of variables of whether landowners harvested timber in the previous five years and whether they intend/plan to harvest timber in the coming five years. The sociodemographic variables $(O C)$ collected in this study primarily consisted of age, gender, education, income, and occupation. Besides, we also considered the effect of landowners' living area which consisted of metropolitan area/suburb area, town/county, and rural/village area, as well as their return from forestland which was measured as the percentage of annual household income from forestland. The specific description for these variables, including definition (i.e., type of variables), is included in Table 1. The third category of $C P$ included different variables in terms of required conditions of certification program. Specifically, respondents were asked to indicate their likelihood of participating in certification program if it had a given condition to participate such as RMNP, if the program requires landowner to have a management plan; ROPI, if the landowner agrees that allowing periodic on-site inspection of forestry practices is a drawback of participation; $\mathrm{RPFMH}$, if the landowner is required to use a professional forester to manage forestland; RICP, whether landowners themselves are required to be involved in some part of the certification progress; and RIRP, if the landowner is required to make the full inspection summary results available to the public. These were measured in a 5-point Likert scale (1, definitely unlikely; 5 , definitely likely), but were later converted to a binary dummy variable. This was performed by converting the values of 4 (somewhat likely) and 5 (very likely) into 1 , and the remaining values of 1-3 (that represented unsure or unlikely) into 0 . In addition, we also considered variables related to landowners' familiarity and interest degree for forest certification (Table 1).

\section{Results}

\subsection{Landowners' Knowledge and Attitudes Towards Forest Certification}

Familiarity with forest certification among landowners was very low (Figure 1). Almost $38 \%$ of the respondents reported that they had never heard of the concept (not familiar at all) before receiving the survey; about $20 \%$ of the respondents indicated that they had heard forest management certification before (slightly familiar) but did not understand its meaning. About $22 \%$ of the respondents indicated that they had at least a minimal understanding of forest certification (very familiar), and only $2 \%$ of the respondents said that they had an extensive understanding of forest certification (extremely familiar).

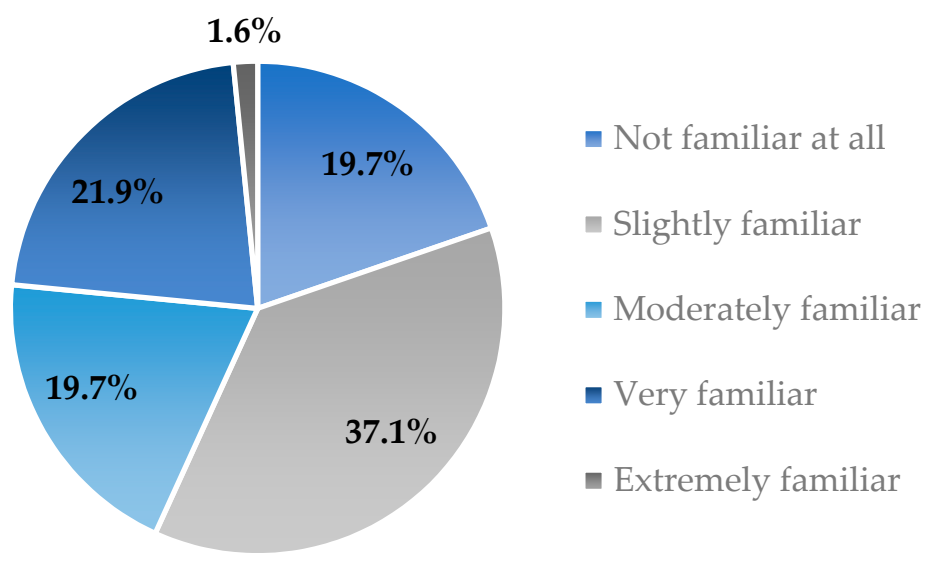

Figure 1. Familiarity with forest certification among respondents $(n=507)$. 
Even landowners had a low familiarity with forest certification, after giving them a brief description and introduction for forest certification such as the associated benefits for adopting forest certification and the purpose of certification, etc. About $63 \%$ of the respondents expressed some interest in participating in forest certification. To test the hypothesis that landowners might be more interested in adopting forest certification if they were more aware of this concept [10], we used Kendall's rank correlation tau to examine their correlation. The correlation result $(p=0.22)$ suggested that there was no significant correlation between them, so the premise was incorrect.

\subsection{Characteristics of Subgroup Landowners}

We classified the respondents into different subgroups according to their familiarity with the forest certification program (Table 2). Respondents in the familiar group $(\mathrm{n}=117)$ were those who reported that they understood the basic concepts or general certification process or have been involved in the certification process before. By contrast, the respondents in the not familiar group $(n=388)$ were those who never heard the concept before or have heard it but did not know/understand what it means before receiving our survey. Results of ANOVA tests indicated that there were typological differences in terms of respondents' socio-demographics and their forestland characteristics between those two subgroups. No significant difference was found in the average age between these two subgroups, but a marked distinction was found in their education level, income level, living area, as well as occupation. Specifically, the percentage of respondents in the familiar group who gained a bachelor/higher degree (76.9\%) was significantly higher than the not familiar group $(56.2 \%)$, while the percentage of who did not complete high school in this group $(1.7 \%)$ was much lower than the not familiar group $(14.9 \%)$. In terms of income level, $17 \%$ of respondents in the familiar group had an annual income level greater than RMB 75,000 , whereas this number was only $6 \%$ in the not familiar group. Almost half of (51.9\%) the respondents in the not familiar group lives at the rural/village area which was marked higher than the percentage (28.5\%) in the familiar group. By examining the respondents' occupation, results suggested that over half of the respondents (57.3\%) in the familiar group were professional managers while almost half of the respondents in the not familiar group were farmers (49.7\%). In addition, the forestland characteristics were also examined for these two subgroups and no substantial difference was found for tenure, importance of timber production, and whether to harvest timber in the near future (Table 2). Respondents in both groups saw a high importance in timber production and they both intended to harvest timber in the near future. The average forestland size was about 125 hectares in the not familiar group and it was around 192 hectares in the familiar group. In terms of having a management plan for their forestland, a relatively higher percent of respondents in the familiar group (62\%) had a management plan than those in the not familiar group (49\%). Regarding respondents' future plan of forestland, over two-thirds of respondents in both groups indicated to self-manage it, whereas $16 \%$ of respondents in the not familiar group planned to sell/rent out, but only $6 \%$ in the familiar group. 
Table 2. Demographics and ownership characteristics among landowner subgroups.

\begin{tabular}{|c|c|c|}
\hline & \multicolumn{2}{|c|}{ Familiarity with Forest Certification } \\
\hline & Not Familiar $(n=388)$ & Familiar $(n=117)$ \\
\hline Average age & $38^{a}$ & $39^{a}$ \\
\hline \multicolumn{3}{|l|}{ Education } \\
\hline -High school degree/vocational training (\%) & $28.9^{\mathrm{a}}$ & $21.4^{\mathrm{a}}$ \\
\hline -Did not complete high school (\%) & $14.9^{\mathrm{a}}$ & $1.7^{\mathrm{b}}$ \\
\hline -Bachelor/higher $(\%)$ & $56.2^{\mathrm{a}}$ & $76.9^{b}$ \\
\hline \multicolumn{3}{|l|}{ Income } \\
\hline$-<$ RMB 20,000 (\%) & $14.9^{\mathrm{a}}$ & $12.0^{\mathrm{a}}$ \\
\hline -RMB 20,000-50,000 (\%) & $53.9^{\mathrm{a}}$ & $44.4^{\mathrm{ab}}$ \\
\hline -RMB 50,000-75,000 (\%) & $25.3^{\mathrm{a}}$ & $26.5^{\mathrm{a}}$ \\
\hline$\rightarrow$ RMB 75,000 (\%) & $5.9^{\mathrm{a}}$ & $17.1^{\mathrm{b}}$ \\
\hline \multicolumn{3}{|l|}{ Living area } \\
\hline Metropolitan (\%) & $15.6^{\mathrm{a}}$ & $41.0^{\mathrm{b}}$ \\
\hline Town/county (\%) & $32.5^{\mathrm{a}}$ & $30.5^{\mathrm{a}}$ \\
\hline Rural/village (\%) & $51.9^{\mathrm{a}}$ & $28.5^{b}$ \\
\hline \multicolumn{3}{|l|}{ Occupation } \\
\hline -Forester $(\%)$ & $2.6^{\mathrm{a}}$ & $2.6^{\mathrm{a}}$ \\
\hline -Professional manager (\%) & $26.0^{\mathrm{a}}$ & $57.3^{b}$ \\
\hline -Government employee (\%) & $5.7^{\mathrm{a}}$ & $10.3^{\mathrm{a}}$ \\
\hline -Farmer $(\%)$ & $49.7^{\mathrm{a}}$ & $9.4^{\mathrm{b}}$ \\
\hline -Retired/businessman/others (\%) & $16.0^{\mathrm{a}}$ & $20.5^{\mathrm{a}}$ \\
\hline Average ownership size (hectares) & $124.8^{\mathrm{a}}$ & $192.4^{b}$ \\
\hline Tenure (year) & $23.4^{\mathrm{a}}$ & $17^{\mathrm{a}}$ \\
\hline Have a forest management plan (\%) & $49.2^{\mathrm{a}}$ & $61.5^{b}$ \\
\hline Importance of timber production ( 5 scales) & $3.57^{\mathrm{a}}$ & $3.80^{\mathrm{a}}$ \\
\hline Intend to harvest timber in the near future & $58.8^{\mathrm{a}}$ & $59.8^{a}$ \\
\hline \multicolumn{3}{|l|}{ Acquisition mode of forestland } \\
\hline Purchase $(\%)$ & $23.3^{a}$ & $40.2^{\mathrm{ab}}$ \\
\hline Rent/traded $(\%)$ & $54.4^{\mathrm{a}}$ & $44.1^{\mathrm{a}}$ \\
\hline Inherited $(\%)$ & $23.3^{\mathrm{a}}$ & $15.7^{\mathrm{a}}$ \\
\hline \multicolumn{3}{|l|}{ Future plan of forestland } \\
\hline -Continue to self-manage it (\%) & $66.5^{\mathrm{a}}$ & $72.6^{\mathrm{a}}$ \\
\hline- Sell $/$ rent it $(\%)$ & $15.7^{\mathrm{a}}$ & $6.0^{\mathrm{b}}$ \\
\hline -Pass it to family (\%) & $17.8^{\mathrm{a}}$ & $21.4^{\mathrm{a}}$ \\
\hline
\end{tabular}

Note: $\mathrm{a}, \mathrm{b}$ means with different subscripts are statistically different.

\subsection{Landowners' Accepted WTA and Affecting Factors}

Results of the survey data revealed that respondents' accepted minimum timber price increase averaged $18 \%$ from the current timber price for them to certainly have their forestland certified. Additionally, the calculated expected/average poplar timber price was around RMB660 ( USD 96.5) / $\mathrm{m}^{3}$ based on the past 15 years' prices (2005-2020) (Figure 2); as a result, the accepted timber price increase for respondents to participate in forest certification was around RMB120 ( USD 7.6) $/ \mathrm{m}^{3}$. 


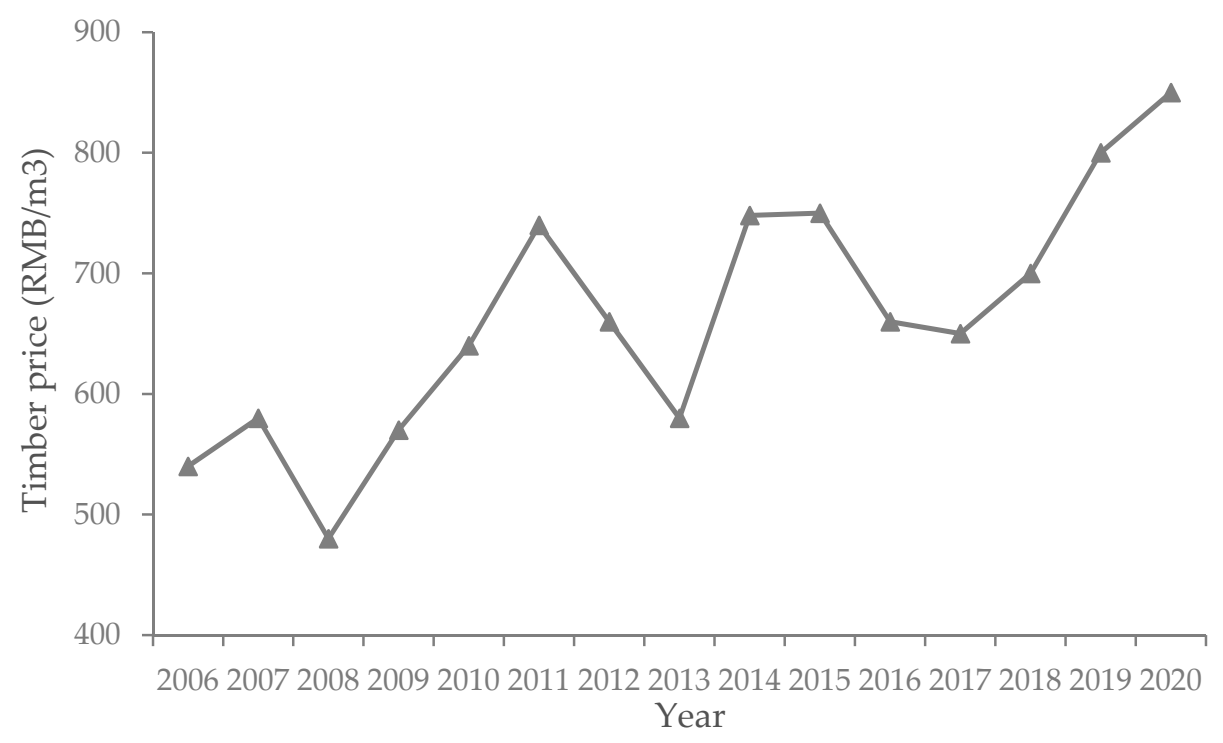

Figure 2. Poplar timber price, 2005-2020 $\left(\mathrm{RMB} / \mathrm{m}^{3}\right)$.

Multicollinearity was examined by calculating the index of variance inflation factors (VIFs) among all independent variables (Table 3) and results showed that they were less than the critical threshold of 10 [33], indicating that multicollinearity was not a concern in this model. Initially considered values but exhibited VIF value higher than 10 (i.e., variables under conditions of participation: whether participation would require thorough involvement in the certification process or making part of the summary inspection results available to the public) were removed from the final regression model. Tobit regression results were summarized in Table 3 . The results revealed variables in the sociodemographic group-age was not significantly related to respondents' WTA compensation, but gender $(p<0.10)$ had a positive and significant association with their WTA compensation for participating in a forest certification program. This result implies that male respondents requested a higher WTA compensation than their female counterparts. A similar result was found for the education variable of did not complete high school $(p<0.01)$. This positive result indicates that respondents who did not complete high school ask for a higher WTA compensation than those who at least have a high school education in terms of adopting forest certification. Variables of income and the percentage of household income comes from forestland were not significantly associated with respondents' WTA compensation. For variables related to occupation, a positive and significant relationship was found for the occupation variable of government employee $(p<0.10)$, which implies that WTA goes up if a respondent is a government employee. As expected, the variable of rural/village in terms of living area $(p<0.001)$ had a significant and positive association with respondents' acceptable compensation. This positive coefficient indicates that respondents who are living in a rural/village area demand more WTA compensation to have their forestland certified.

The results of the forestland and ownership characteristics group indicated that forestland size was significantly $(p<0.001)$ and negatively related to a respondent's WTA compensation for certifying their forestland. This result suggests that the WTA decreases with respondents' land size. Regarding the forestland management objective variable of the importance of managing forestland for protecting biodiversity, there was a significant and positive $(p<0.05)$ correlation with respondents' WTA. A similar positive and significant result was observed for the dummy variable representing whether respondents have a management plan for their forestland $(p<0.01)$. This observation implies that respondents' WTA is higher for those who have a management plan than those who do not have one. No significant association was found for other variables in this category including the acquisition mode of forestland, tenure, as well as future harvesting plan. 
Table 3. Results of Tobit regression affecting factors for landowners' willingness to accept (WTA) compensation to have their forestland certified.

\begin{tabular}{|c|c|c|c|}
\hline Variable & Coefficient (Std. err.) & Significance & VIF \\
\hline Intercept & $113.63(21.66)$ & $<0.001$ & - \\
\hline \multicolumn{4}{|c|}{ Sociodemographic variables } \\
\hline AGE & $-0.10(0.30)$ & $>0.10$ & 1.74 \\
\hline GENDER & $10.90(5.57)$ & $<0.10 *$ & 1.59 \\
\hline Did not complete high school & 27.68 & $<0.01^{* * *}$ & 1.77 \\
\hline INCOME & $-1.87(2.88)$ & $>0.10$ & 1.52 \\
\hline Forester & $-2.73(10.82)$ & $>0.10$ & 1.84 \\
\hline Professional manager & $2.16(3.73)$ & $>0.10$ & 2.88 \\
\hline Government employee & $19.88(10.21)$ & $<0.10 *$ & 1.69 \\
\hline Farmer & $3.18(7.13)$ & $>0.10$ & 3.07 \\
\hline Rural area/village & $24.23(5.86)$ & $<0.001^{* * *}$ & 2.12 \\
\hline DEPFOR & 10.11(7.96) & $>0.10$ & 1.31 \\
\hline \multicolumn{4}{|c|}{ Forest resource characteristics } \\
\hline SIZE & $-0.016(0.006)$ & $<0.01^{* * *}$ & 1.36 \\
\hline IMPBIO & $5.69(2.26)$ & $<0.05^{* *}$ & 2.06 \\
\hline IMPREC & $-0.73(2.47)$ & $>0.10$ & 1.77 \\
\hline Purchase & $0.53(1.80)$ & $>0.10$ & 1.46 \\
\hline Rent/traded & $-3.62(5.06)$ & $>0.10$ & 1.61 \\
\hline TENURE & $0.13(0.14)$ & $>0.10$ & 2.13 \\
\hline FUHAR & $-7.18(6.04)$ & $>0.10$ & 2.21 \\
\hline MANAPLAN & $13.22(5.12)$ & $<0.01^{* * *}$ & 1.64 \\
\hline \multicolumn{4}{|c|}{ Conditions of participation } \\
\hline RMNP & $11.38(4.93)$ & $<0.10^{*}$ & 1.44 \\
\hline ROPI & $6.52(4.45)$ & $>0.10$ & 1.24 \\
\hline RPFMH & $14.98(5.02)$ & $<0.01 * * *$ & 1.44 \\
\hline RICP & $-5.07(4.93)$ & $>0.10$ & 1.44 \\
\hline RIRP & $4.13(4.82)$ & $>0.10$ & 1.46 \\
\hline \multicolumn{4}{|c|}{ Others } \\
\hline IMPTIM & $1.79(2.39)$ & $>0.10$ & 2.39 \\
\hline FAMI & $-2.28(2.24)$ & $>0.10$ & 1.46 \\
\hline INTERE & $0.90(2.22)$ & $>0.10$ & 127 \\
\hline Sigma & $44.88(1.41)$ & $<0.001$ & - \\
\hline
\end{tabular}

Note: ${ }^{* * *} p=0.01 ;{ }^{* *} p=0.05 ;{ }^{*} p=0.10$. VIF: variance inflation factors.

The certification program design characteristics category included different requirements of the certification program after participating, specifically, the requirements of having a management plan, on-site inspection, having a professional forester to manage and harvest forestland, as well as involvement of the certification process and publishing summary inspection results to the public. Among these variables, results revealed that there was a significantly positive $(p<0.10)$ association between the requirement of having a management plan with respondents accepted compensation for adopting forest certification. A similar result was found for the requirement of using professional forester/loggers $(p<0.01)$ to harvest forestland. Both results suggest that respondents' WTA increases with the requirements of having a management plan and having trained foresters/loggers to harvest timber for participating in a forest certification program.

Regarding the variable in the group of market drivers, results suggested that the economic importance of timber sales was not significantly and positively associated with respondents' WTA. Likewise, with regard to the variables describing respondents' familiarity and interests in forest certification, results in this research revealed that there was no significant association between them with respondents' WTA. 


\section{Discussion}

The survey results of this study indicated that landowners in Shandong Province have a generally low familiarity with forest certification, which was consistent with the previous associated studies [15,17,18,34]. The study of Chen et al. [34] found that, in China, wood product manufacturing was not familiar with forest certification either. The correlation results suggested that there was no significant association between landowners' familiarity with forest certification and their willingness to participate in this program. This was not in line with the studies of Mercker and Hodges [35] and Sun et al. [36], who reported that there was a positive association between landowners' knowledge of forest certification and their likelihood of participating.

Significant differences were found in landowners' demographics between the familiar and not familiar group. In terms of education and household income, the familiar group landowners were more educated and had a higher income level than those in the not familiar group, which was consistent with He et al. [16], who stated that education was positively associated with landowners' familiarity with forest conservation programs. In addition, results indicated that occupation was associated with landowners' familiarity with forest certification since almost two-thirds of landowners in the familiar group worked as foresters or professional managers. Regarding ownership variables, we found a significant difference in ownership size between these two subgroups, suggesting a positive association between ownership size with a landowner's familiarity with forest certification. Between the two subgroups, a significant difference was found in the availability of a written forest management plan, which implied a positive correlation between having a management plan and landowners' familiarly with forest certification.

The ballpark estimation for landowners' accepted WTA to participate in a forest management certification program was around RMB120 (USD 17.6) $/ \mathrm{m}^{3}$ in Shandong Province. This estimated amount was very close to a local city of Linyi's news report [6], which showed that the price for certified poplar forest products is averagely $20 \%$ higher than those not certified. This could bring about extra income of RMB100 ( USD 14.6) $/ \mathrm{m}^{3}$ for landowners [6]. The RMB20 ( USD 2.9) $/ \mathrm{m}^{3}$ difference resulted from the average price difference; specifically, the RMB120 ( USD 17.6) $/ \mathrm{m}^{3}$ was estimated based on the average timber price of the past 15 years while in the news it only used the average timber price of 2013.

Regression results of this study displayed that a landowner's minimum accepted compensation for participating in a forest certification program was influenced by a series of ownership and forestland characteristics. Among the sociodemographic variables, a positive and significant coefficient was found for gender, indicating that male landowners require a higher WTA compensation than their female counterparts for adopting a forest certification program. Research [20-22] found that women are more concerned with environmental issues than men, which possibly relates to the higher WTA for male landowners. A positive and significant coefficient was found for the variable of education, which implies that if a forest household's highest education level is not finishing high school, he/she would demand an RMB28 ( USD 4.1) higher compensation for participating in forest certification than those who at least finish high school. Likewise, a positive and significant effect was found for the variable of government employee, which suggests that if a landowner is/was a government employee, he/she asks a higher WTA compensation for having his/her forestland certified than others. Similarly, those who lived in a rural/village area requested more compensation for them to have their forestland certified, which is possibly because landowners in this area are more financially reasoned to their own forestland. In addition, the variable of income was not significantly associated with landowners requested compensation to seek forest certification. This finding was in line with Kline et al. [20], who stated that willingness to accept compensation for landowners to participate in forest conservation program was quite consistent among different income categories.

A positive coefficient before the variable of size indicated that a landowner who owns a large acreage size of forestland requires less compensation to definitely have their 
forestland certified. This observation is not particularly surprising considering that the average per unit certification cost would be lower for a large forestland size than a small size of forestland, and this result was consistent with studies by Kilgore et al. [19] and Bateman et al. [37]. As expected, forest owners who indicated a high importance of their forestland in protecting nature and biodiversity demand a higher compensation to enroll in forest certification. Landowners would expect a higher compensation amount to pay off their benefits reduction from timber activities for providing the public benefits such as protecting biodiversity. Regarding whether landowners have a management plan for their forestland, a positive and significant coefficient was observed, which implies that landowners who have a management plan would request a higher WTA compensation than those who do not have one. This observation might due to the fact that having a management plan could increase their management costs indirectly.

A positive and significant association was found between different requirements of the forest certification program and landowners' WTA compensation for adoption. Specially, if the certification program request landowners to use a professional forester to manage and harvest their forestland after certification, landowners would demand a higher WTA compensation than otherwise. Moreover, landowners indicated a higher WTA compensation if the certification program requires them to have a written management plan after participation. A possible reason behind those two observations is that hiring a professional forester or having a written management plan might indirectly increase their management costs.

\section{Conclusions}

Overall, this study sheds some light on the analysis of landowners' preference and willingness to accepted compensation for adopting forest certification in Shandong Province, China. Compensation needed for landowners, in terms of increased timber revenue, to consider participating in the certification program was estimated at RMB120 ( USD 17.6)/ $\mathrm{m}^{3}$ to have their forestland certified. In other words, it may be the case that landowners might not find it financially worthwhile to participate unless the timber price increases by this amount. This finding may be helpful to government agencies and non-government institutions that are currently considering designing incentive mechanisms to encourage landowners' participation. Moreover, this compensation amount was influenced by a group of ownership and forestland characteristics. For example, to encourage/motivate landowners participating in forest certification, a greater/higher compensation might be required for those who are living in a rural/village area and those who have a low education level such as people who did not finish high school. On the contrary, a lower compensation might be enough for landowners with larger acreage size. In addition, landowners whose forests provide biodiversity protection or recreational uses expected a higher compensation to get certified. There are existing mechanisms that can be implemented by landowners to get financial compensation for such biodiversity conservation and recreational services. One typical example is the implementation of the Ecosystem Services Procedure (ESP) from the FSC scheme. This ESP program could be implemented together with forest certification, which could be helpful in motivating landowners to participate in a certification program. Moreover, another important incentive-based program might be the creation of a carbon credits program which might also bring financial benefits for landowners who value a high importance of biodiversity protection.

In addition, a few caveats about the data analysis and modeling in this study should be noted. First, landowners' willingness to accept compensation was computed by averaging 15 years' poplar timber price which is changeable and uncertain regarding the market condition. The other options could have been direct subsidy or payment from government or other entities to participating landowners. However, in the absence of such programs, increase in timber revenue through higher timber price was used instead to elicit willingness to accept value. Admittedly, this measure was not the same as value elicitation question typically using in soliciting WTA but is a reasonable alternative and 
perhaps free from hypothetical bias associated with accepting or rejecting a hypothetical bid. Second, some of the variables originally measured on a 5-point Likert scale were converted into binary dummy variables because of the better fit in the regression model. While it is common to adopt such a convention in empirical analysis, its impact on the results is unknown and cannot be completely ruled out.

Future studies could focus on identifying landowners' desirability to learn about forest certification and their preferred and accepted learning methods (e.g., workshop, webinar, or video conference, etc.) would be needed to improve landowners' awareness and familiarity with forest certification in China.

Supplementary Materials: The following are available online at https:/ /www.mdpi.com/2071-105 $0 / 13 / 2 / 903 / s 1$.

Author Contributions: N.T. designed the analysis, interpreted result, and prepared the manuscript. N.P. provided input in the questionnaire design, and edited the draft. N.T. and F.L. implemented the survey in Shandong, China. All authors have read and agreed to the published version of the manuscript.

Funding: This research was funded by the W. K. McClure Scholarship Program in the Center for International Education at the University of Tennessee.

Institutional Review Board Statement: The study was conducted according to the guidelines of the Declaration of Helsinki, and ap-proved by the Institutional Review Board (or Ethics Committee) of University of Tennessee (protocol code IRB 16-02999-XP and 20 June 2016).

Informed Consent Statement: Informed consent was obtained from all subjects involved in the study.

Data Availability Statement: Data sharing not applicable.

Acknowledgments: We would like to thank the W. K. McClure Scholarship Program in the Center for International Education at the University of Tennessee for the funding support in data collection in China. We also would like to thank the officials at the Forest Service Department in Shandong Province for their help in the field work. We are thankful to the College of forestry, natural resources and agriculture at University of Arkansas at Monticello for their funding support of publication.

Conflicts of Interest: The authors declare no conflict of interest.

\section{References}

1. Shapiro, J. Mao's War Against Nature: Politics and the Environment in Revolutionary China; Cambridge University Press: Cambridge, UK; New York, NY, USA, 2001.

2. Liu, J. China's road to sustainability. Science 2010, 328, 50. [CrossRef] [PubMed]

3. Li, N. Sustainable Forest Management in China: Achievements in the Past and Challenges Ahead. In Challenges and Opportunities for the World's Forests in the 21 st Century; Fenning, T., Ed.; Springer: Berlin/Heidelberg, Germany, 2014. [CrossRef]

4. Hou, F.; Wen, Y. China's forest certification development and its impacts on China's forest products trade. In Proceedings of the International conference on economics and management (ICEM), Suzhou, China, 2-3 July 2016; pp. 1-10.

5. Institute for Agriculture Trade Policy (IATP). Forest Certification Frequently Asked Questions; Community Forestry Resource Center: Minneapolis, MN, USA, 2004.

6. Forest Stewardship Certification in Linyi City of Shandong. Available online: http://sd.ifeng.com/news/chengshi/detail_2013 _11/11/1443067_0.shtml (accessed on 5 September 2020).

7. Hayward, J.; Vertinsky, I. High expectations, unexpected benefits: What managers and owners think of certification. J. For. 1999, 97, 13-17.

8. Bensel, T. Promoting certified sustainable forestry on private woodlots in north-western Pennsylvania: Challenges and opportunities. Local Environ. 2001, 6, 257-278. [CrossRef]

9. Rickenbach, M.G. Forest certification of small ownerships: Some practical challenges. J. For. 2002, 100, 43-47.

10. Kilgore, M.A.; Leahy, J.E.; Hibbard, C.M.; Donnay, J.S. Assessing family forestland certification opportunities: A Minnesota case study. J. For. 2007, 105, 27-33.

11. Perera, P.; Vlosky, R.P.; Hughes, G.; Dunn, M.A. What do Louisiana and Mississippi nonindustrial private forest landowners think about forest certification? South. J. Appl. For. 2007, 31, 170-175. [CrossRef]

12. Leahy, J.E.; Kilgore, M.A.; Hibbard, C.M.; Donnay, J.S. Family forest landowners' interest in and perceptions of forest certification: Focus group findings from Minnesota. North. J. Appl. For. 2008, 25, 73-81. [CrossRef] 
13. Zhao, J.; Xie, D.; Wang, D.; Deng, H. Current status and problems in certification of sustainable forest management in China. Environ. Manag. 2011, 48, 1086-1094. [CrossRef]

14. Ma, Z.; Butler, B.J.; Kittredge, D.B.; Catanzaro, P. Factors associated with landowner involvement in forest conservation programs in the U.S.: Implications for policy design and outreach. Land Use Policy 2012, 29, 53-61. [CrossRef]

15. Chen, J.; Innes, J.L. The implications of new forest tenure reforms and forestry property markets for sustainable forest management and forest certification in China. J. Environ. Manag. 2013, 129, 206-215. [CrossRef]

16. He, M.; Wu, Z.; Li, W.; Zeng, Y. Forest certification in collectively owned forest areas and sustainable forest management: A case of cooperative-based forest certification in China. Small Scale For. 2015, 14, 245-254. [CrossRef]

17. Tian, N.; Poudyal, N.C.; Lu, F. Understanding Landowners' interest and willingness to participate in forest certification program in China. Land Use Policy 2017, 71, 271-280. [CrossRef]

18. Tian, N.; Lu, F.; Joshi, O.; Poudyal, N.C. Segmenting Landowners of Shandong, China Based on Their Attitudes towards Forest Certification. Forests 2018, 9, 361. [CrossRef]

19. Kilgore, M.A.; Snyder, S.A.; Schertz, J.; Taff, S.J. What does it take to get family forest owners to enroll in a forest stewardship-type program? For. Policy Econ. 2008, 10, 507-514. [CrossRef]

20. Kline, J.; Alig, R.J.; Johnson, R.L. Fostering the production of nontimber services among forest owners with heterogeneous objectives. For. Sci. 2000, 46, 302-311.

21. Van Herzele, A.; van Gossum, P. Owner-specific factors associated with conversion activity in secondary pine plantations. For. Policy Econ. 2009, 11, 230-236. [CrossRef]

22. Knoot, T.G.; Rickenbach, M.; Silbernagel, K. Payments for ecosystem services: Will a new hook net more active family forest owners? J. For. 2015, 113, 210-218. [CrossRef]

23. Bell, C.D.; Roberts, R.K.; English, B.C.; Park, W.M. A logit analysis of participation in Tennessee's forest stewardship program. J. Agric. Appl. Econ. 1994, 26, 463-472. [CrossRef]

24. Nagubadi, V.; McNamara, K.T.; Hoover, W.L.; Mills, W.L. Program participation behavior of nonindustrial forest landowners: A probit analysis. J. Agric. Appl. Econ. 1996, 28, 323-336. [CrossRef]

25. Tian, N.; Lu, F. Adaptive management decision of agroforestry under timber price risk. J. For. Econ. 2013, 19, 162-173.

26. Kordelas, G.; Daras, P. Robust SIFT-based feature matching using Kendall's rank correlation measure. In Proceedings of the 2009 16th IEEE International Conference on Image Processing (ICIP), Cairo, Egypt, 7-10 November 2009; pp. 325-328. [CrossRef]

27. Lindhjem, H.; Mitani, Y. Forest owners' willingness to accept compensation for voluntary conservation: A contingent valuation approach. J. For. Econ. 2012, 18, 290-302.

28. Beach, R.H.; Pattanayak, S.K.; Yang, J.C.; Murray, B.C.; Abt, R.C. Econometric studies of non-industrial private forest management a review and synthesis. Forest Policy Econ. 2005, 7, 261-281. [CrossRef]

29. Martín-López, B.; Montes, C.; Benayas, J. The non-economic motives behind the willingness to pay for biodiversity conservation. Biol. Conserv. 2007, 139, 67-82. [CrossRef]

30. Tobin, J. Estimationn of relationship for limited dependent variables. Econometrica 1958, 26, 24-36. [CrossRef]

31. Ammmemiya, T. Tobit models: A survey. J. Econom. 1984, 24, 3-16. [CrossRef]

32. Halstead, J.; Lindsay, B.; Brown, C. Use of the Tobit Model in Contingent Valuation: Experimental Evidence from the Pemigewasset Wilderness Area. J. Environ. Manag. 1991, 33, 79-89. [CrossRef]

33. Ghimire, R.; Green, G.; Poudyal, N.; Cordell, H.K. Do outdoor recreation participates place their lands in conservation easements? Nat. Conserv. 2014, 9, 1-18. [CrossRef]

34. Chen, J.; Innes, J.L.; Kozak, R.A. An exploratory assessment of the attitudes of Chinese wood products manufacturers towards forest certification. J. Environ. Manag. 2011, 92, 2984-2992. [CrossRef]

35. Mercker, D.; Hodges, D.G. Modeling landowner behavior regarding forest certification. In Proceedings of the 16 th Central Hardwood Forest Conference, West Lafayette, IN, USA, 8-10 April 2008.

36. Sun, X.; Sun, C.; Munn, I.A.; Hussain, A. Knowledge of public assistance programs and application behavior of nonindustrial private forest landowners: A two-step sample selection model. J. For. Econ. 2009, 15, 187-204.

37. Bateman, I.J.; Diamond, E.; Langford, I.H.; Jones, A. Household willingness to pay and farmers' willingness to accept compensation for establishing a recreational woodland. J. Environ. Plan. Manag. 1996, 39, 21-43. [CrossRef] 